\title{
ENFORCEMENT OF THE CREDIT AGREEMENT WITH THE GUARANTEE OF THE MORTAGE FOR THE DEVELOPER OF RESIDENTIAL CONSTRUCTION WITH CREDIT
}

\author{
I Nyoman Widana \\ Master for Public Notary, University of Mataram \\ Email: inyomanwidana@unram.ac.id
}

\begin{abstract}
In article 2 paragraph (2) of the Mortgages Law on section 22 subsection (9) has degraded the mortgages rights on the object that is concerned to be logged by the land Office over the books of the land and rights of a dependent as well as the Certificate of land entitlement which has been free from the rights of the original relations. However, section 22 subsection (9) of the mortgages law does not specify the logging enforcement of time limit by the Office of the Land Commission as specified in article 22 paragraph (8). This research aimed to analyse the enforcement of credit agreement residential construction with dependent rights in the city of Mataram. This article has two problems as follow: what are the factors affecting the enforcement of the rights of dependent credit residential construction in the city of Mataram and how is the responsibility of the notary against the deed of credit agreement made in residential construction. This research is empirical legal research seeking at how the law in empirical field. The research uses descriptive qualitative analysis supported by qualitative approaches. Based on the results of the research, enforcement of a residential construction that charged on right dependents between company and bank has previously started by an agreement in which the agreement was made to facilitate the parties in conducting the process of loading a dependent right which the rights and obligations of the parties are set forth in the cooperation agreement.
\end{abstract}

Keywords: Construction, Credit, Right Of Dependants

\section{A. INTRODUCTION}

The credit agreement is an agreement in which is prevalent in the field of banking law. In the credit agreement, there are two parties involved, i.e. banks as creditors and the debtor as a customer of a credit agreement which is commonly applied by banking institutions, the present form could be made by the non-authentic agreement and the authentic agreement (a deed made in the 
presence of a notary public). A credit agreement is the agreement of principal (main agreement) that must be carried out when both sides, namely, the creditors and the debtor who has agreed to provide and use credit facilities. On credit agreements, it was included also the existence of collateral material to guarantee repayment of the debt from the debitor. The material warranty must be made in a treaty of guarantees (acesoir agreement) have the right material and assesoir (additional).

The Bank distributes practically a wide variety of credit in accordance with the needs of the community. Property rights is one of the most high collateral assets to obtain credit because it is a basic guarantee in the form of fixed objects, registered with the land and the increased prices. If the proprietary land then it will be easy to note that the land in question may be possessed and used without time limit (Baiq Henny Paramitha Rosandi, 2016: 424). A guarantee of land typically granted by the debtor to the creditor as one of the conditions to provide a protection for the lender, at any time it occurred over compulsory payments paid by the debtor to the creditor in accordance with the clause credit agreement mutually agreed earlier.

Therefore, related to the needs of the community, therefore Law Number 4 of 1996 is dependent on the land along with the objects related to the land, herein after abbreviated to Mortgages Law. Registration is mandatory to be registered as Dependants of the rights contained in article 13 paragraph 1 . Furthermore, the activities of the registration Rights Agreements required by the land deed official (PPAT) and check the completeness of the Administration as well as the physical data, to ensure the validity of land ownership. In article 13 paragraph (2) stating that the grant of rights of compulsory enrolled Dependents less than 7 (seven) days after the signing of the deed of Grant Dependent (APHT), and Land Deed Official required to send us the corresponding APHT and files other necessary administration to the Office of the Land. In fact, the right of dependents is not listed in accordance with the provisions of the rights of dependents. 
Dependent rights was the right of guarantee charged on land rights as stipulated in Law Number 5 of 1960 on the basic rules of agrarian issues, including or not including other objects which constitute a single entity with the land, for the repayment of certain debt, which gives precedence to the position that certain creditors against creditors other creditors, rightsDependents is one of the institutions of the right material, guarantees that the inception of the agreement. If the imposition of treaty Entitlement Agreements had been made, the next step registration Rights Dependent on the land Office as set forth in a government Law Number 24 of 1997 on Land Registration. Registration Rights a dependent is applied by several stages or processes to issuance the certificate of entitlement Dependants by the Land Office the city of Mataram as mentioned in article 14 of Law Number 4 of 1996 on Dependent upon Lands along the objects related to the land, namely:

1. as evidence of the right of Dependants, the Office published the Land Rights Certificate Dependents in accordance with the legislation in force.

2. certificate of Entitlement Dependants as referred to in paragraph (1) contains irah irah-with the words " for the sake of Of Justice Under The One Almighty God

3. certificate of Entitlement Dependants referred to in subsection (2) has the same eksekutorial with the power of the Court ruling which has acquired permanent legal force and apply sbagai replacement grosse acte hypotheek all about land rights .

4. Unless enforced by other land rights Certificate, which has been labelled the imposition of entry Dependent Rights as stipulated in article 13 paragraph (3) is returned to the holder of the rights to the land in question.

5. certificate of Entitlement Dependants left to Right holders dependents.

From the above characteristics, the Deposit Rights provide legal certainty to the parties concerned. Droit de preferent and Droit de suite as privileges granted to the creditors of the Mortgage Holders, if any Insurers' burdensome burdensome objects for which the creditors repaid are not known to them, the validity of the Deposit Rights shall be clearly stated which 
receivables and to what amount is guaranteed and which items are guaranteed, this is what is meant by the terms of the speciality principle (Famaldiana Mayanti Liza, 2016: 507).

To get a clear picture, it is necessary to know the process of making Deed of Mortgage Rights (APHT), then the process of registration until the birth of Mortgage Rights, then after the debtor can pay off debt debt, carried out roya rights process. As it is known that the Deed of Assignment Rights (APHT) is made before the authorized Land Deed Official (PPAT) in accordance with the PPAT working area, so APHT is an authentic deed.

After the Deed of Mortgage Rights is made by the parties concerned, within 7 (seven) days shall be registered to the local Land Office complete with supporting documents, then within 7 (seven) days after the receipt of complete registration, the Land Office shall be required to issue a certificate of Mortgage Right. Likewise, after the debtor repays his debts, the creditor issues a letter of roya mortgage, registered Roya mortgage application to the local Land Office and within 7 (seven) working days after the application of Roya registration is received completely, the Land Office shall abolish in the land book as well as in the Book of Mortgage Rights of the burden of the Deposit Rights.

The process of this mortgage rights is in accordance with the provisions of Article 2 paragraph (1) of the Mortgage Law that the Mortgage's Rights are indivisible, unless agreed in the Deed of Assignment Rights. The exception as referred to in the provision of Article 2 paragraph (1) is that for the interest of the Depositary (Debtors) can be contracted and mentioned in the Deed of Assignment of the Insured Rights (APHT) concerned that debt repayment is guaranteed to be made by installments equal to the value of each - the units that are part of the object of the Deposit Rights (Sutan Remy Sjahdeini, 1999: $5)$.

Based on the above provisions, the Deposit Rights may be partially offset against the object of the Deposit Rights due to the repayment of a portion of the debt from the Depositary, although it is not previously 
promulgated clearly the part of the Mortgage object that is exempted from the burden of the Deposit, either by an authentic deed or a non-authentic deed. If it is observed from the provisions of Article 124 paragraph (2) Regulation of the Minister of Agrarian Affairs / Head of National Land Agency Number 24 of 1997 which states:

"Registration of the Deposit Insurance Rights on some objects of the Deposit Rights may also be carried out, althoughit it is not in compliance with the provisions of paragraph (1), namely the registration of the deprivation of the mortgage on some of the object of mortgage rights may be based on the repayment of a portion of the debt secured by the object of mortgage rights consisting of several rights and the removal of the mortgage rights due to the repayment of a portion of the debt which is agreed upon in the deed of granting the mortgage rights. Based on the disposal of the Deposit Rights on a part of the object of the Mortgage Right by the holder of the Mortgage Rights as stated in the authentic deed or the statement under the hand with clearly stated part of the object of the Deposit Rights that is exempted from the burden of the Mortgage right ".

As explained earlier in accordance with Article 2 Paragraph (2) of the Mortgages Law, if the Deposit Rights is imposed on certain land rights, it can be agreed upon in the Deed of Assignment of the Mortgage concerned, that the repayment of the guaranteed debt can be done by installment equal to the value of each - the land rights that are part of the object of the Mortgage Rights, which will be exempted from the mortgage, so then the Deposit Insurance shall only burden the remaining object of the Deposit Rights to guarantee the remaining outstanding debt.

\section{B. PROBLEM STATEMENT}

The formulation of the problem is used to confirm the problems to be studied so that it will be easier for author in conducting research. Based on the introduction, the author has two problems as follows:

a. How is the implementation of the residential construction credit agreement that is borne by the Mortgage Rights in the city of Mataram?

b. What is the responsibility of the notary to the deed made in the residential construction credit agreement in the city of Mataram? 


\section{RESEARCH METHODS}

Field data is data obtained directly through interviews with respondents either structured or unstructured. Structured interviews are conducted based on a list of feasts provided by the researcher. Unstructured interviews are interviews conducted without reference to the list of celebrations. The material evolves according to the answers and the information directly. In the preparation of this thesis, the location of the study was chosen in the city mataram.

\section{RESEARCH RESULT AND DISCUSSION}

\section{Exercise Of The Rights To Land Are Encumbered By Dependants} Credit Construction Of Residential In The Mataram City

According to the explanation of revelation Hidayat, legal staff of Debale Property Lombok who explained that in the implementation process of the construction of the residential credit charged right dependents between Debale with banks, be preceded by a cooperation agreement where the agreement was made to facilitate the parties in the process of loading a dependent right where are the rights and obligations of the parties are set forth in the cooperation agreement. Debale prior to the imposition of a dependent rights need to gather the necessary files in a dependent rights, the imposition of peroses as for some of the files that are in need of:

1. Photo ID card copy of the parties

\section{Certificate}

3. Tax ID and sppt

After you complete and file the required letter of credit financial approval from the bank was out then bring the files debale to the notary public that already set by both sides. That is where there are rights and obligations that must be met by both parties, in which debale obliged 
prepare files required in the imposition of the right bank and any dependants have the obligation of issuing subpoena financing credit (Interview with Wahyu Hidayat SH, 2017).

If the authors have associated with the theory used to answer and analyze problems first, in this case the author is using the theory of the effectiveness of the law in which to run the effectiveness of laws there are some things or factors that affect the enforcement it self :

a. Factors of ruling themselves.

b. Factors in law enforcement, is on the parties that make up as well as applying the law.

c. Factors means or facilities that support law enforcement.

d. Community Factors, namely the environment where the law applies or applied.

e. Cultural Factors, is as a result of the work, copyright and flavor that is based on human intention in the Association life.

The fifth factor of the above law enforcement, then in this study the authors do at Debale Property, there is still the issue that the author found mainly from factors of society itself, which according to revelation hidayat legal staff Debale Property which explains the obstacles or barriers that are often encountered in the implementation of the rights of dependent credit construction residential is in terms of collecting the files, sometimes the parties file a complete lack of which causes our company waiting for the completeness of the file of the parties, when the file is complete our party Debale directly overlooking the notary office which is already specified.

Likewise also in implementation in the field of law enforcement factors is others have done for real and firmly in accordance with the provisions of the applicable legislation. Surely this is a form of obedience and compliance carried out bymDebale credit construction in the implementation of the rights of a dependent with the Bank Tabungan Negara (BTN) Branch the city of Mataram. 
Barriers that authors can not just on sheer file collection but related payments made, when customers pay with cash or paid off no problem but when paying customers with our residential credits then there is a little bit of resistance at payment.

Any obstacle come not only from the recipient of the credit alone but hambatanpun come from the lender which is usually the bank to process credit approval letter backdated it took a very long time until 2 weeks arrived with 4 months ever. Party bank in the roya contruction our residential credits, butuk a very long time in which the process being undertaken by the bank roya fastest 2 weeks duration.

Dependent rights laws related to the rights of a dependent imposition peroses implemented through two stages, namely:

a. Stages of awarding a dependent with a Deed did he Grant Dependants by the land deed official, hereinafter referred to as a Land Deed Official, in agreement with the Preceded debts.

b. Stage pendaftaranya by the land Office, which is the time of the birth of the Dependent Rights charged (R. Subekti, 1989: 128).

Land Deed Official is a public officer who is authorized to make the deed of transfer of rights over land and other deed in order the imposition of land rights, a form of deed in the set, as evidence of specific legal deeds he did regarding the land located in the area It works each. In other words that the Deed Of Grant Agreements (APHT) made by the Land Deed Official is the authentic deed according to the provisions of article 10 of the Law the rights of dependants that:

"The granting of rights to dependents is preceded with a promise to give the right debt repayment guarantees as dependents, who poured in and is part an integral part of the treaty concerned debts or other agreements that raises the debt." 


\section{The Responsibility Of A Notary In The Residential Contruction Credit Agreement}

The responsibility of a Notary as a prophet is born of the obligation and authority given to him, the duty and authority are legally and bound since the Notary uttered his juralam oath as a Notary, according to Nico distinguishes Notary responsibility into 3 kinds:

a. The civil Notary's responsibility to material truth to the deed he made.

b. The responsibility of a Notary criminal to the material truth in the deed he made.

c. The responsibility of a Notary based on a notary's rule of material truth to the truth of the deed he made.

The responsibility of the Notary explained by nico if the authors associate with the theory of legal responsibility in this thesis research conducted at Debale Property where the responsibility of the Law lies with the notary public as the general authority authorized to make the deed of granting the mortgage and power of attorney to impose the right the dependency between Debale and BTN that I met there is no deed with problem made by Notary or ppat in the deed he made between Debale with BTN branch mataram but if in the future the notarial deed or land deed official is problematic then the notary is responsible for the deeds he makes of civil, criminal, or Notary's own code of conduct.

The responsibility of Notary in a civil case in which the parties of Debale and BTN feel harmed by the deed made then the Notary is obliged to compensate for the deed he made due to the negligence of the notary itself. Criminal liability when a Notary performs an unlawful act, for example, if a notary in a transitional transaction of deed of sale and purchase deliberately implies a price lower than the actual price that can be categorized as fraud (Interview with Nengah Sukma, 2017).

The responsibility of a Notary in a code of ethics of a Notary has been regulated by Law Number 30 of 2004 which is replaced by Law Number 2 of 2014 regarding the notarial position of sanction against the 
deed which he made down from the authentic deed to the deed under the hand while for the notary is given a sanction starting from reproof to dismissive termination.

In carrying out its functions and responsibilities as a general official, it is not uncommon for the Notary to deal with legal matters, which in the case of this law notary must provide testimony and testimony concerning the deeds he made In order to the Notary when performing his duties fulfill all the requirements relating to the performance of office duties Notary, for the sake of securing the interest of the public, since the Notary is appointed by the government, not for the self-interest of the Notary itself but for the benefit of the community it serves, since Notary only pours the wishes of the parties into the deed made (interview with Notary Samsaimun, 2017).

Notary in making the deed has the responsibility of both legal and ethical responsibility to the Notary, to be responsible for the deeds made, the mistake that often occurs in Notary mostly caused by the negligence of the Notary, because it does not respect the rule of law and the values ethics. The legal product of a Notary is an authentic deed in the form of a Notary deed and not all public officials have the authority to do so. Notary must have good knowledge and skill in order to pour the wish and need of society into a deed. To be eligible to become Notary one must fulfill the requirements as regulated in Article 3 UUJN, as follows (Kartini Soedjendro, 2001: 43):

a. Indonesian citizens;

b. Be cautious of God Almighty;

c. Aged at least 27 (twenty seven) years;

d. Physically and mentally healthy as stated by a health certificate from a doctor and a psychiatrist;

e. Graduated with a law degree and a graduate degree in stratum;

f. Have been apprenticed or have worked as a Notary employee within 24 consecutive months at the Notary's office on their own initiative or on 
the recommendation of the Notary Organization after graduating from the two stages of the notary;

g. Not a civil servant, a state official, an advocate or not in another position which the law is prohibited from being caught in the position of Notary; and

h. Have never been imprisoned by a court decision that has obtained permanent legal force for committing a crime punishable by imprisonment of 5 (five) years or more.

A person may be said to be a public official if it meets 3 (three) conditions, namely: he is a government employee; served as a leader; and his duty is to take care of the interests of the people. Notaries have the following characteristics: as a position, a Notary has certain authority, is appointed and dismissed by the government, does not receive salary / pension from the appointee and the accountability of his work to the public.

Notary's office has two essential characteristics and characteristics, non-independence and independence in providing assistance to its clients. It is a credo, a belief, that these two attributes are inherent and identical to the behavior of the offender. Although administratively a Notary is appointed and dismissed by the government, it does not mean Notary becomes the subordinate (subordinate) who appoints the government.

Notary in exercising his / her authority shall be based on the principles of good duty of office of notary. In the general principles of good governance (AUPB) are known to the following principles:

a. The principle of equation;

b. The principle of trust;

c. The principle of legal certainty;

d. The principle of precision;

e. The principle of reasoning;

f. Prohibition of abuse of authority; 
g. Prohibition of acting arbitrarily

These principles are very important for a Notary public Notary in order to be able to run its task properly and does not conflict with the rules of the applicable law. For the purposes of the execution of the duties of the Office of Notary public, coupled with the principle of Proposionalitas and Basic Professionalism (Philipus M. Hadjon, 2002: 270).

The Notary is one part of the people of Indonesia, so in accordance with the principle of the equation then the Notary must not discriminate community with one another in providing service well seen from socio-economic or other reasons. In addition, based on the principle of trust then a Notary is party to a very trusted by the community in this respect is the parties go before the Notary.

One form of the position of trust that is by looking at the Notary who has an obligation to keep secret everything about deed made in accordance with the oath or promise has been pronounced before being lifted as Notary unless a law determines the other. Thus, the limit only legislation can instruct a notary public to divulge the contents of the deed and the description or statement that is known to the notary, which deals with the making of the deed in question (Wawan Tunggal Alam, $2001,85)$. This is in accordance with the content of article 16 paragraph (1) letter f UUJN: "secret of everything regarding the Deed made and any information obtained in order to manufacture Certificate in accordance with the oath/pledge of Office, unless the Statute otherwise". Oath or promise contains two things that should be understood, namely;

1. Mandatory Notary responsible to God because the oath/promise spoken based on their respective religions, thus meaning that everything that is done in the Notary Office will be requested to perform tasks was to have in the the desired shape of the Lord; 
2. Mandatory Notary responsible to the country and society, meaning that the country has given confidence to run as a task of the country in the field of civil law, namely in making evidence in the form of a deed which has the power of proof perfect, and to the people who have believed that the notary is able to formulate his will into the form of a notary deed and believe that a notary was able to save (Sphinx) any description or speech given before a notary.

Based on the principle of legal certainty, the notary is obliged to adhere to the legal rules regarding certificate. This is caused when a notary public are bound to the rules of the applicable law then it can provide a legal certainty for the people who need Notary services. Furthermore, in accordance with the principle of accuracy then a Notary is required to examine the whole of the evidence shown and listening to the statement or description as a basis in the manufacture of a deed. This is in accordance with article 16 paragraph (1) letter a UUJN which States that, "a notary public in the running task his Office is obligated to act carefully". The implementation of the principle of accuracy required in the making of this certificate by:

1. Do an introduction to confronts, based on his identity disclosed to the Notary.

2. Asking then listening and observing the desire or the will of the parties to the (FAQ).

3. Examine the letter related to the desire or the will of the parties.

4. To give advice and make the framework act to meet the desire or the will of the parties.

5. Meet all administrative techniques of manufacture of notary deed, such as reading, signing, provided a copy and filings with securities to minuta.

6. Perform other obligations relating to the implementation of the duties of the Office of notary public. 
7. In the practice of a notary public who examined it will be found, another reason why the notary does not want to give or refuse, on the grounds between the deed be made incompatible with the honorarium will be accepted Notaris. Honorarium is regulated in article 36 paragraph (1) of Law Number 2 of 2014 of the Office of notary public: "notary public is entitled to receive an honorarium upon legal services provided in accordance with those powers". Here in after in article 36 paragraph (2) of Law Number 2 of 2014 on Notary Office mentioned that: "the magnitude of the honorarium received by the Notary based on the value of the economical and sociological value of any deed he made".

8. On the basis of article 4 paragraph (2) UUJN, "the notary swears an oath or promise to keep secret the contents of the deed and information which he obtained in the exercise of the Office of notary public". On the basis of article 16 paragraph (1) letter f UUJN:

"The entire contents of the deed consisting of the beginning of the deed, the deed and the end of the deed, the deeds made by Notary as defined in Article 54 UUJN, as well as the explanations and series of facts notified by the client to the Notary both listed in the deed or not listed in the deed in the process of making deed ".

In addition to the obligation to be performed by a Notary, there is also a prohibition for a Notary. Prohibition for a Notary is regulated in Article 17 paragraph (1) UUJN is as follows (Eis Fitriyana Mahmud, 2013: 18):

a. Conducting a position outside the territory of his / her position;

b. Leaving his / her office area of more than 7 (seven) consecutive working days without valid reason;

c. Caught as a civil servant;

d. Concurrently serving as a state official;

e. Concurrently serving as an advocate;

f. Accepting a position as a leader or an employee of a state-owned enterprise, a region alowned enterprise or a private enterprise; 
g. Accepting a position as Land Acquisition Official and / or Class II Auction Officer outside the place of Notary;

h. Become a Notary Substitute; or

i. Doing other work that is contrary to religious norms, morals, or propriety that may affect the honor and dignity of Notary's office.

If a Notary violates the prohibition referred to in Article 17 paragraph (1) UUJN mentioned above, the Notary may be subject to the following sanctions:

a. Written warning;

b. Suspension;

c. Dismissal with respect, or

d. Dismissal with disrespect

\section{E. CLOSING}

Implementation of the burden of Mortgage by the developer of mortgage construction credit between debtor and bank are still obstacles in its implementation namely the obstacles to its disobedient and timely society factor in collecting the necessary file for the process of making Power of Attorney Charging Rights Dependency (SKMHT) and Deed of Assignment Rights (APHT) by Notary / PPAT.

As a logical consequence along with the responsibility of Notary to the public, it shall be ensured the continuous supervision and guidance so that the Notary is always in accordance with the rules of law underlying authority and can avoid the abuse of authority, as well as he should be upheld by a Notary which can be run according to existing law.

\section{BIBLIOGRAPHY}

\section{Books:}

Kartini Soedjendro, 2001, Agreement on Conversion of Conflict Potential Land Rights, Yogyakarta. 
Philipus M. Hadjon, et al., 2002, Introduction to Indonesian Administrative Law, Yogyakarta: Gadjah Mada University Press.

R. Subekti, 1989, Civil Procedure Law, Bandung: Bina Cipta.

Sutan Remi Sjahdeini, 1999, Deposit Rights, Principles, Main Provisions And Problems Faced by Banking, Bandung: Alumni.

Wawan Tunggal Alam, 2001, Law of Talk for Cases in Everyday Life, Jakarta: Popular Milenia.

\section{Journals:}

Baiq Henny Paramitha Rosandi, 2016, Unlawful Sale and Purchase of Land Rights Not Yet Listed, Jurnal IUS, IV, Universitas Mataram,.

Eis Fitriyana Mahmud, 2013, "The Limits of Obligation of Notary Notaries in the Use of Rights in the Criminal Justice Process", Journal, Master Program of Notary, Faculty of Law, Malang: Universitas Brawijaya.

Henni Paramita Rosandi Baiq, 2016, Due to the Sale and Purchase Law of Land Rights Not yet Registered, Journal of IUS, Vol. IV, University of Mataram.

Famaldiana Mayanti Liza, "Legal Implications of Late Registration of Land Transfer Right Certificate (Study at Land Office of Bima Regency), Journal of IUS (legal and justice review) 4.3 (2016) .http: // jurnalius. ac.id/ ojs / index.php / journal IUS / article / view / 409 / pdf_22.

\section{$\underline{\text { Regulations }}$}

Law Number 5 of 1960 on Basic Regulation of Agrarian Principles, State Gazette of The Republiic of Indonesia Number 104 of 1960

Law Number 4 of 1996 on the Deposit Rights, State Gazette of The Republic of Indonesia Number 42 of 1996

Law Number 2 of 2014 on Amendment to Law Number 30 Year 2004 on Position of Notary, State Gazette of The Republic of Indonesia Number 3 of 2014 Government Regulation Number 24 of 1997 on Land Registry, State Gazette Number 59 of 1997 
Government Regulation Number 37 of 1998 on the Regulation of Officials of the Land Deed Authority, State Gazette of The Republic of Indonesia Number 52 of 1998

\section{Interview:}

Data based on interviews with Notary Nengah Sukma 14 June 2017.

Data based on interview with Notary Samsaimun 15 June 2017.

Data from Interview with Wahyu Hidayat SH, legal staff of PT. Debale Property Lombok on June 13, 2017 